\title{
The Subject - A Key Element of the Fugue Form during the 20th Century
}

\author{
GABRIELA VLAHOPOL \\ “George Enescu” National University of Arts Iaşi \\ ROMÂNIA*
}

\begin{abstract}
The great stylistic epochs of the past mostly had syntaxes and specific forms, escaping in the context of the application of polyphonic syntax to the tonal system. The twentieth century, characterized by a continuous mobility and search in the field of the musical language, does not intend to create new musical forms but takes preexisting patterns, which adapt to the creative contexts specific to the composers. Thus, despite the blurring of some of the fundamental elements, other factors of configuration and construction were maintained and amplified, as well as the particular phenomenon, the most significant phenomenon being the development of the thematic principle, which will have its particular manifestations in the fugue form, the diversity of its interpretations bearing the mark of some new directions.
\end{abstract}

Keywords: the fugue form, theme, exposition, 20th century.

\section{Introduction}

A complex thematic form, based on the exposition archetype, the fugue form has as a main constructive reference the thematic articulation, which in the course of the work undergoes more or less considerable transformations, and which, through episodic appearance, determines the organization of the whole in distinct architectural segments with specific functionality. Due to the importance of the theme in establishing the coordinates of the form, the present study deals with several aspects of articulation in the musical context of the 20th century, which are novelties in relation to the knowledge about the theme of the Baroque fugue.

\section{Particularization}

Regarding the intonations employed, as well as the melodic and rhythmic aspects, we have already noted some significant aspects in a previous chapter. We will continue to provide some additional observations on the rhythmic and melodic setting of the fugue themes, particularly focusing on the aforementioned features.

From an intonational point of view, we observe the use of a variety of formulas that refer either to Baroque themes (Gregorian or Protestant choral or instrumental style), or units that process elements adopted from folklore (song

\footnotetext{
*gabrielavlahopol@gmail.com
} 
or dance) or are manifestations of the serial, atonal, tonal-geometric thought of the composers:

- The Gregorian choral style: Erik Satie, Fugue litanique; Dmitri Shostakovich, Fugue IV of 24 Preludes and fugues

- The Instrumental style: George Enescu, Suite op. 20 (first theme); Sigismund Toduţă, Concert no. 2 for string orchestra

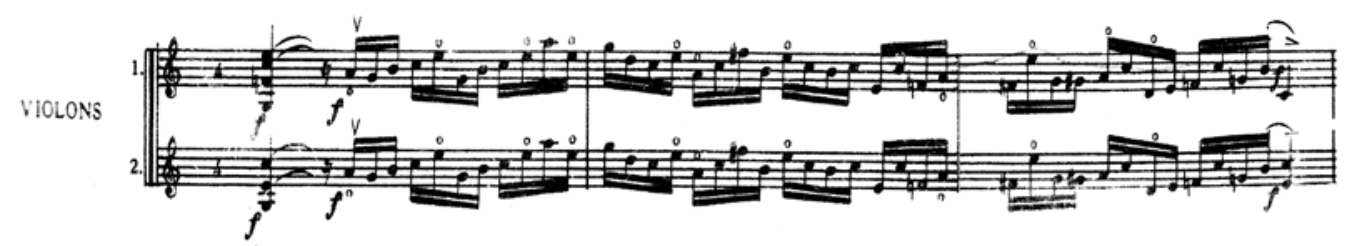

Fig. 1a George Enescu, Suite no. 2 op. 20 for orchestra, part I, theme 1, mm. 1-3

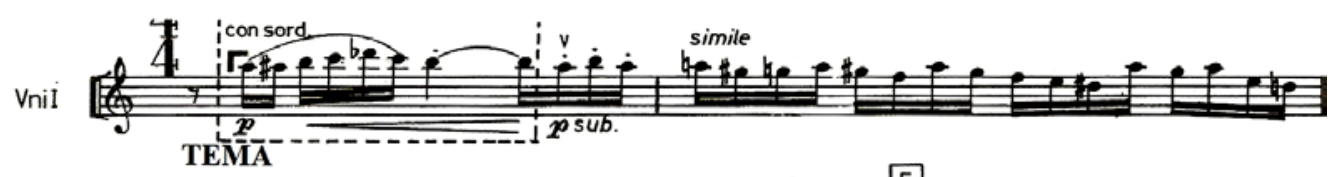

TEM̄Ā

5

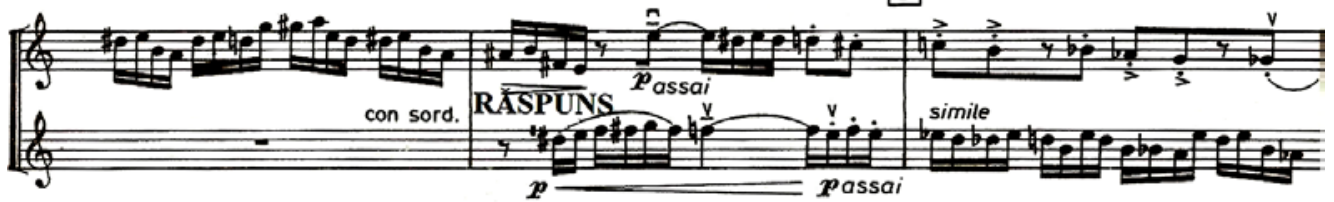

Fig. 1b Sigismund Toduţă, Concerto no. 2 for string orchestra, theme, mm. 1-5

- The Bachian sonority: Dmitri Shostakovich, Quintet op. 57; Max Reger, Variations and fugue on a theme by J.S. Bach;

- The Christmas carol: Sigismund Toduţă, Nainte-mi de curţi, Colo-n josu mai din josu (Before the gate, Down below); George Enescu, Fugue from Suite for piano op. 3;

- The dance: Tudor Ciortea, Octet for wind instruments and piano; Sigismund Toduţă, “Mioriţa” Oratorio;

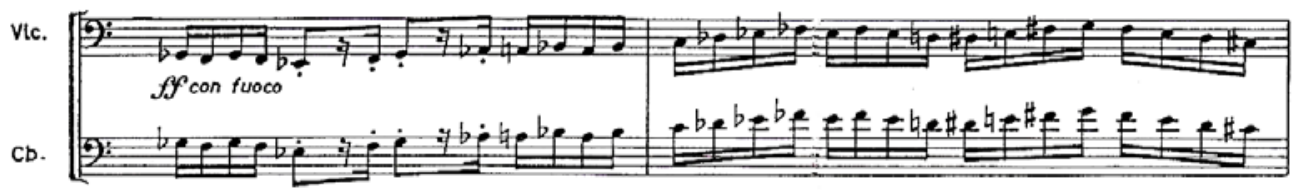

Fig. 2 Sigismund Toduţă, “Mioriţa” Oratorio, Fugue, mm. 1-2 
- Serial theme: Doru Popovici, Symphony II (Spielberg) (fugue theme consisting of 2 complete series);

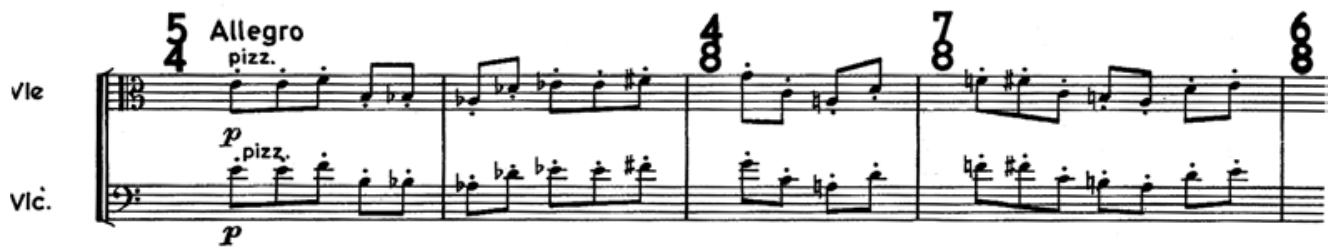

Fig. 3 Doru Popovici, Symphony II (Spielberg), mm. 1-4

- Atonal theme: Arnold Schönberg, Pierrot lunaire - Der Mondfleck;

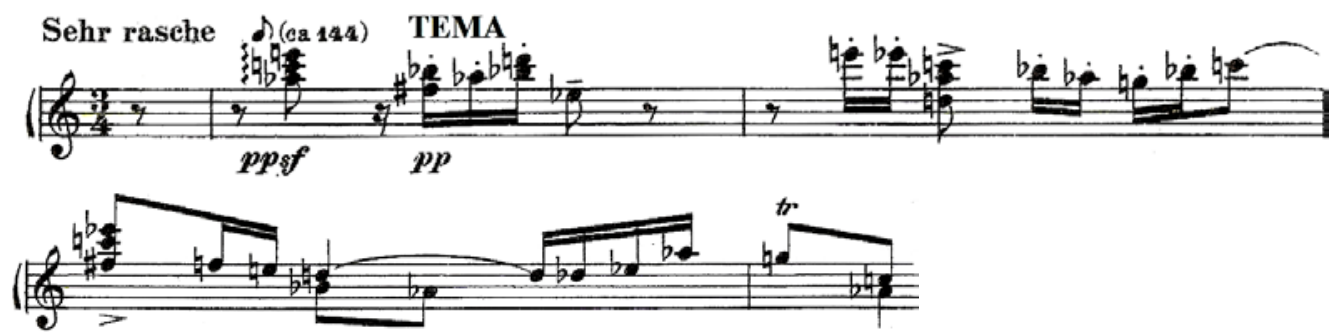

Fig. 4 Arnold Schönberg, Pierrot lunaire, Der Mondfleck, mm. 1-4

- The tonal-geometric theme: Béla Bartók, Music for strings, percussion and celesta, part I;

- The Funnel ${ }^{1}$ theme: Zeno Vancea, Concert for orchestra;
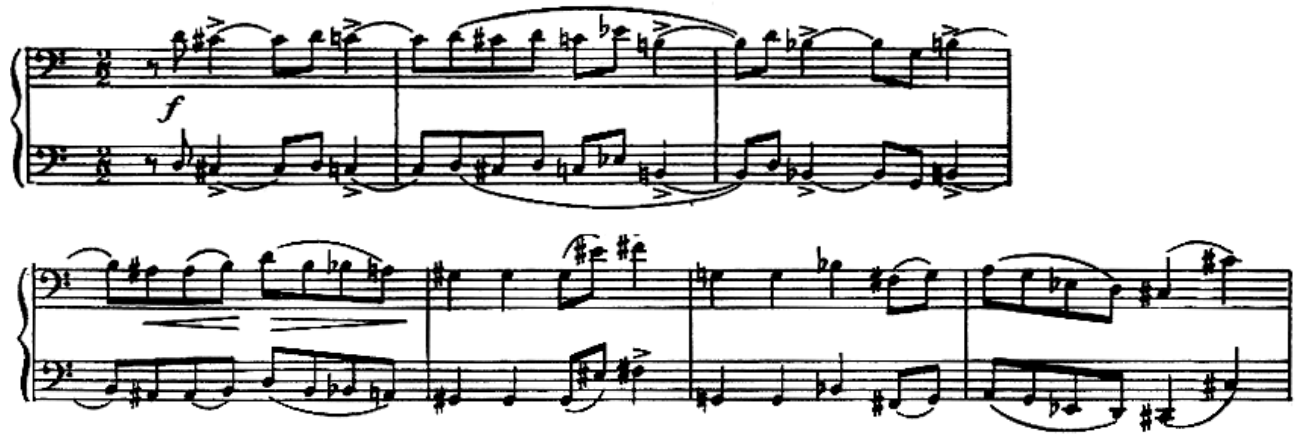

Fig. 5 Zeno Vancea, Concerto for orchestra, Fuga, mm. 1-7

${ }^{1}$ Term introduced by Dan Voiculescu in the work Polyphony of the 20th Century. 
- Chromatically enriched Byzantine sounds: Gheorghe Firca, Contrapuntal sketch on a Byzantine theme;

- The theme without melodic intonations, achieved only by/through acoustic effects: Şerban Nichifor, Anamorphose;
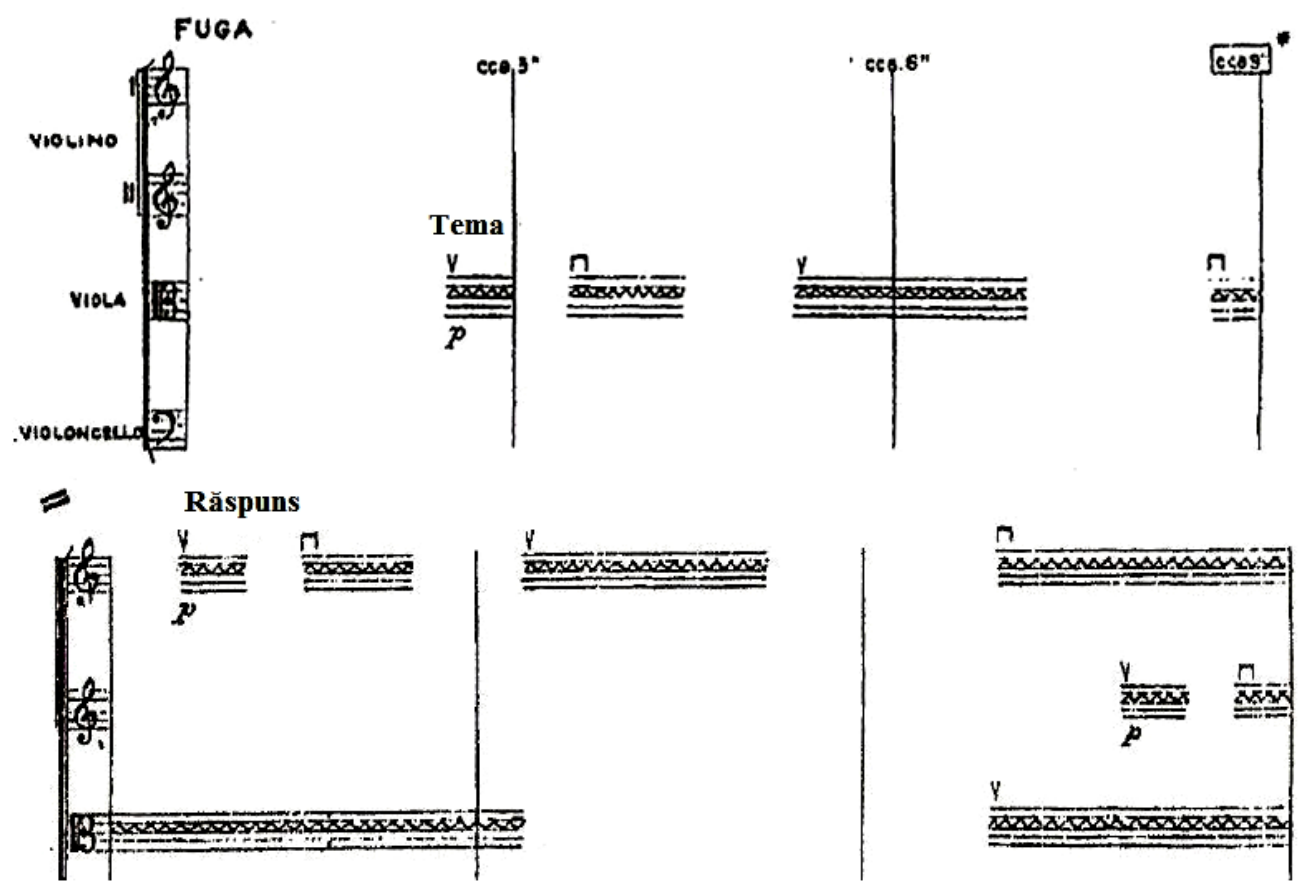

Fig. 6a Şerban Nichifor, Anamorphose, mm. 1-6

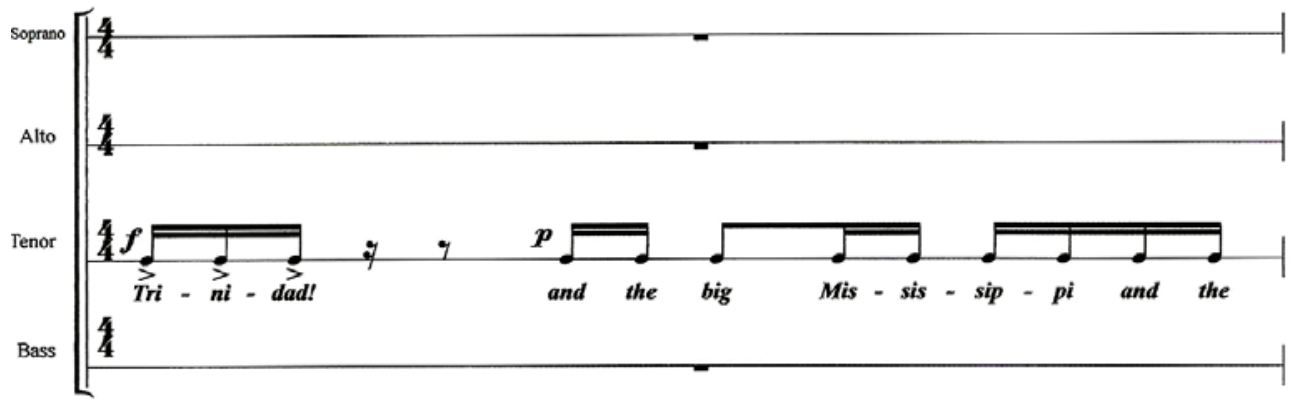




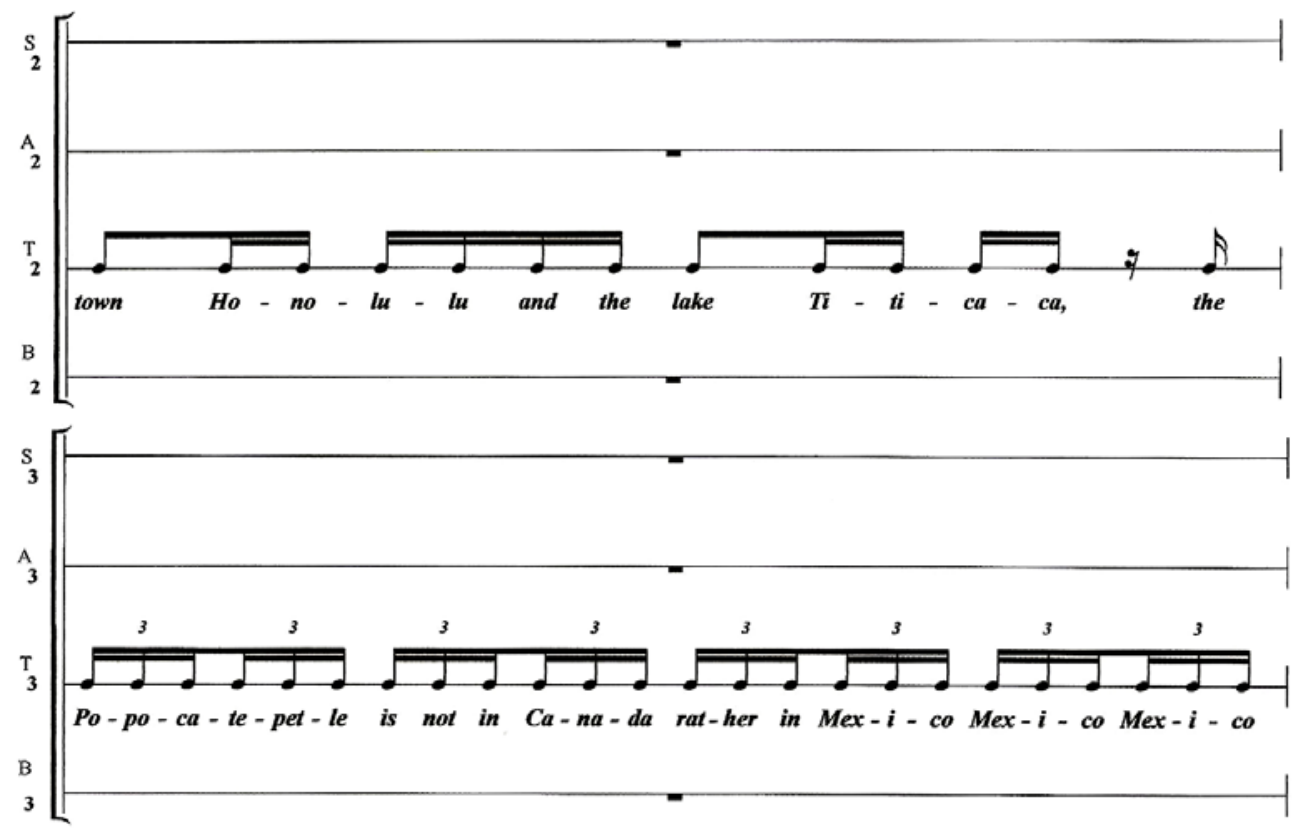

Fig. 6b Ernst Toch, Geographical Fugue, mm. 1-3

The melodic structure of the themes is the direct expression of the composing thought belonging to the authors who approached the fugue technique, a tendency that can be framed in several main directions:

- late romanticism (Max Reger), which exploits tonal thinking in an intensely chromatic hypostasis;

- neo-classical, which takes the Baroque tonalism (George Enescu, Suite op. 3);

- tonal with pentatonic and pre-pentatonic modal influences;

- diatonic modal (Erik Satie);

- tonal system based on the first partials of the natural harmonics series (Paul Hindemith, Ludus tonalis, Trio);

- $\quad$ chromatic modalism (Sigismund Toduţă, Concerto for orchestra no. 2);

- dodecaphonic system;

- $\quad$ atonal system (György Ligeti, Aurel Stroe);

- serialism (Doru Popovici).

In some cases, we even observe certain correspondences between the fugue subjects of some composers and the intonational patterns from the creation of others. In the fugue from Sonata for solo violin by Marcel Mihalovici, the theme takes on variation one of Szymanowsky's choral works (via ornamentation on modal-chromatic basis). 


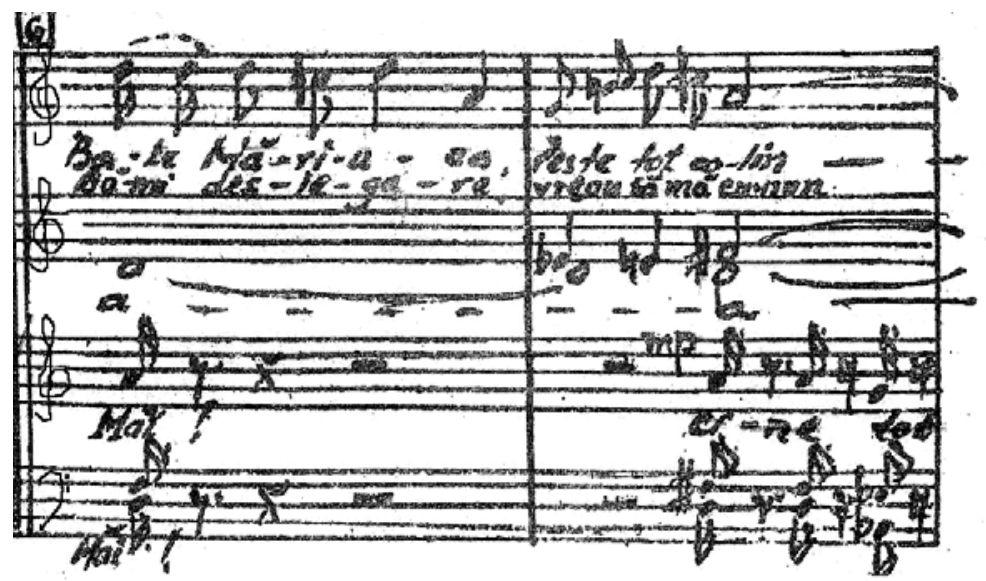

Fig. 7a Karol Szymanowsky, Cine bate, mm. 17-18

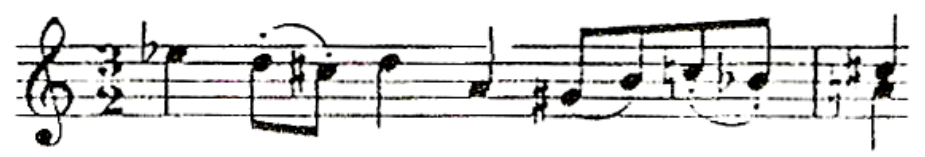

Fig. 7b Marcel Mihalovici, Sonata for solo violin, theme, mm. 1-2

From the point of view of the interval structure, the Baroque fugue was based on scalar formulas, connected by leaps not exceeding a sixth, but framed in a clearly defined tonal context In the twentieth century, due to the progressive expansion of the tonal system, on the one hand by the increase of the chromatic complexity, and on the other by mixing with elements of modal thinking in various hypostases up to atonal and serial thinking, we see a change in the melodic design of the themes, manifested by the introduction of successive leaps, sometimes exceeding an octave.

We observe a differentiation on this line between the tonal or the tonemodal themes and those of intense chromatic or atonal conception: gravitational thinking stands out by itself, the melodic formulas are individualized and are recognizable precisely through the logic of melodic organization and clear latent harmonic chains; the atonal system (serial, geometric) can only be imposed upon hearing via shocking formulas, leaps or successions of unexpected leaps, or specific melodic formulas.

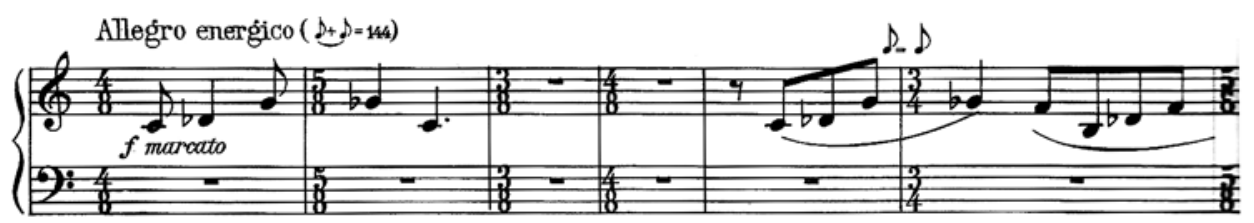



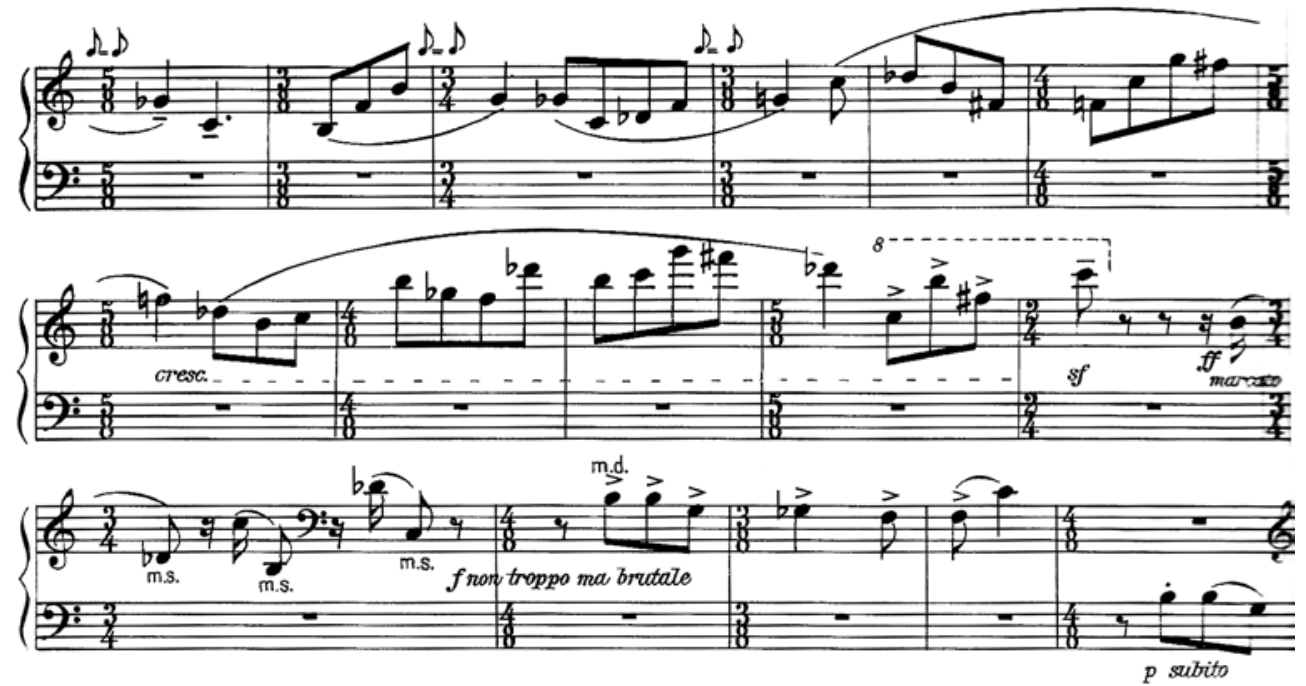

Fig. 8 Aurel Stroe, Sonata for piano, part III, Fuga, mm. 1-22

Due to the "rugged" structure of such thematic constructions, we can no longer speak, as in the case of Bachian fugues, of the existence of a welldefined climax, but of an ensemble of musical and extra-musical factors (text in the case of vocal or vocal-symphonic fugues, emission mode, attack type, intervalic, rhythmic formulas, etc.), which determines a discursive route with particular expressive meanings oscillating between pure objectivism (Hindemith, Ravel) and maximum subjectivity (in Wozzeck, each theme of the triple fugue bears the mark of the character's symbolic nature, becoming a leitmotiv).

From a rhythmical point of view, we observe the same delimitation of the manifestation tendencies also applicable to intonation, this time focused on two major sub-classes:

- the neoclassical line, which takes on the rhythmic formations specific to the Baroque fugue, whether of a vocal nature in stile antico, or of an instrumental style, characterized by the fluency of the sixteenth grouping.

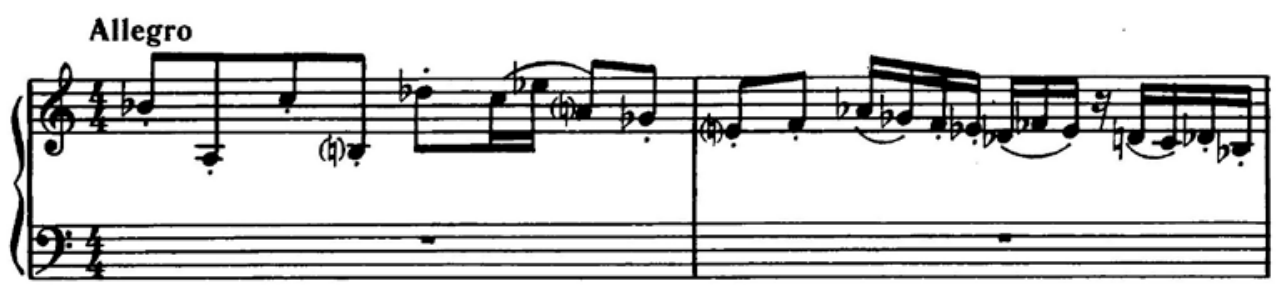

Fig. 9 Arthur Honegger, Prelude, Arioso et Fughette sur le nom BACH, Fughette, mm. 1-2 
- with the rhythmic factor emancipation in the 20th century music, there is a diversification of the rhythmic formulas, the expression of the thematic articulation being influenced by the punctuated formulas, by the rhythmic ornamentation by multiple divisions of the time units, by the association of asymmetric formulas disproportionate as number of elements and temporal aspect.

The diversification of the rhythmic side at the level of the theme will extend to the variation of its later aspects (in the median halves), not only by augmentation or diminution, but by the diversification of the rhythmic formulas that alter the grouping of the original values and metro-rhythmic accents (ex. Myriam Marbé, Sonata for two violas, part 2, György Ligeti, Requiem - Kyrie).

We also encounter a metric variation of the themes, highlighted by the polymetry of some thematic articulations (see Aurel Stroe, Fugue from the Sonata for piano).

As with the Baroque fugue themes, we encounter aspects of latent polyphony in the construction of the thematic articulations, yet along a similar line of application of the process. A special type of latent polyphony, particular to the creation following the 1950s, is the one obtained on punctualist bases such as the fugue from the Sonata for solo clarinet by Tiberiu Olah. The apparent planes belonging to the same monody are delineated based on timbre and attack, as well as on the valorisation of the dynamic elements.

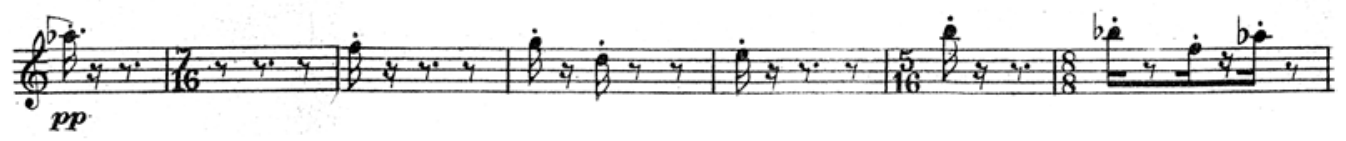

Fig. 10 Tiberiu Olah, Sonata for solo clarinet, theme, mm. 34-40

The tendencies for maximum rationalization of modal structures placed their mark on the ways of conceiving fugue themes. Thus, in serial works, we often encounter quasi-symmetrical thematic constructions, whose internal organization allows - precisely because of the similarity of the variants - their simultaneous processing. For example, the theme of the "fugue" from the Sonata for two violas by Myriam Marbé is subject to multiple permutations, which also give rise to symmetric modules. 


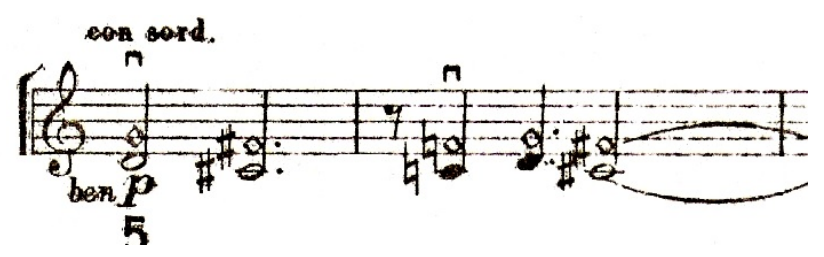

Fig. 11 Myriam Marbé, Sonata for two violas, theme

The whole discourse of the section (Aria) is built up by overlapping and juxtapositions of different variants of the primary and derived series in multiple rhythmic scenes. The relationship of the two structures determines, on the one hand, the sound unity of the whole, and on the other hand, by imprinting the sensation of mono-thematism, it gives birth to the form, which becomes a fugue in a very free aspect. The imitation of the two component voices is never strict, and melodic differences (generated by the many added sounds to the initial series) but especially the rhythmic ones make it sometimes difficult to perceive the imitated model.
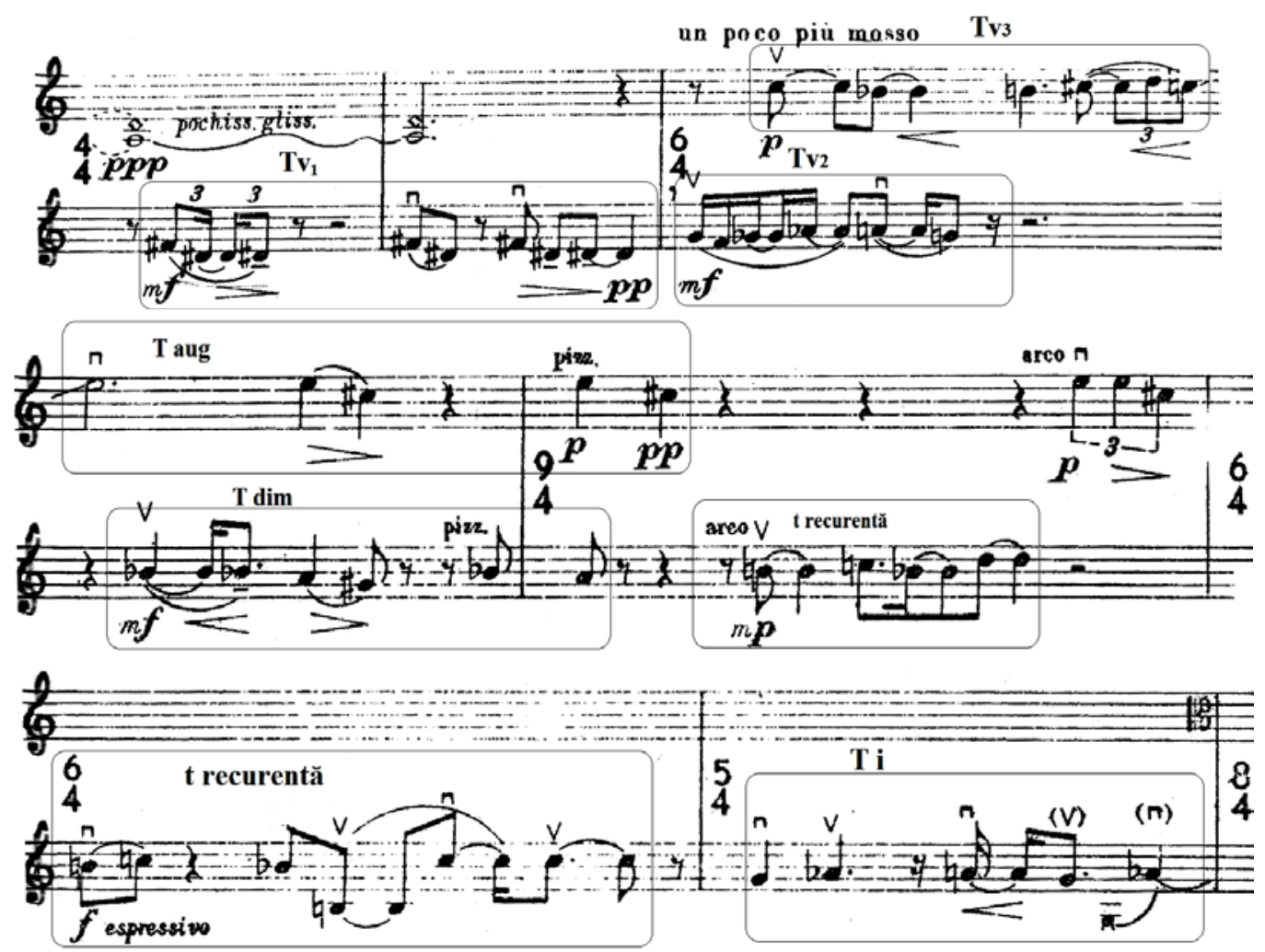

Fig. 12 Myriam Marbé, Sonata for two violas, part II, Aria, mm. 12-18 


\section{Thematic treatment in the fugue exposition}

We will continue to address some of the types of response and the fugue of the 20th century.

- The expositive response is divided into two categories:

1. the octavian response, which continues the traditional closing line of the imitation circle with the return to the base tone (C-G-C). The process is especially applied by neo-classical composers whose extended (tono-modal) tonal language is still dominated by the gravitational dominant functionality (Bartók, Enescu, Shostakovich, Stravinsky, etc.).

2. the non-octavian response can be divided in two subclasses:

- the superior fifth interval response (or lower fourth) without closing the imitative string in the octave circle. In this category, there are the fugue expositions of a considerable number of authors who use intensely chromatic sonorous language, to the limit of atonalism or in the serial works of the composers concerned with constructivism as a way of conceiving creation.
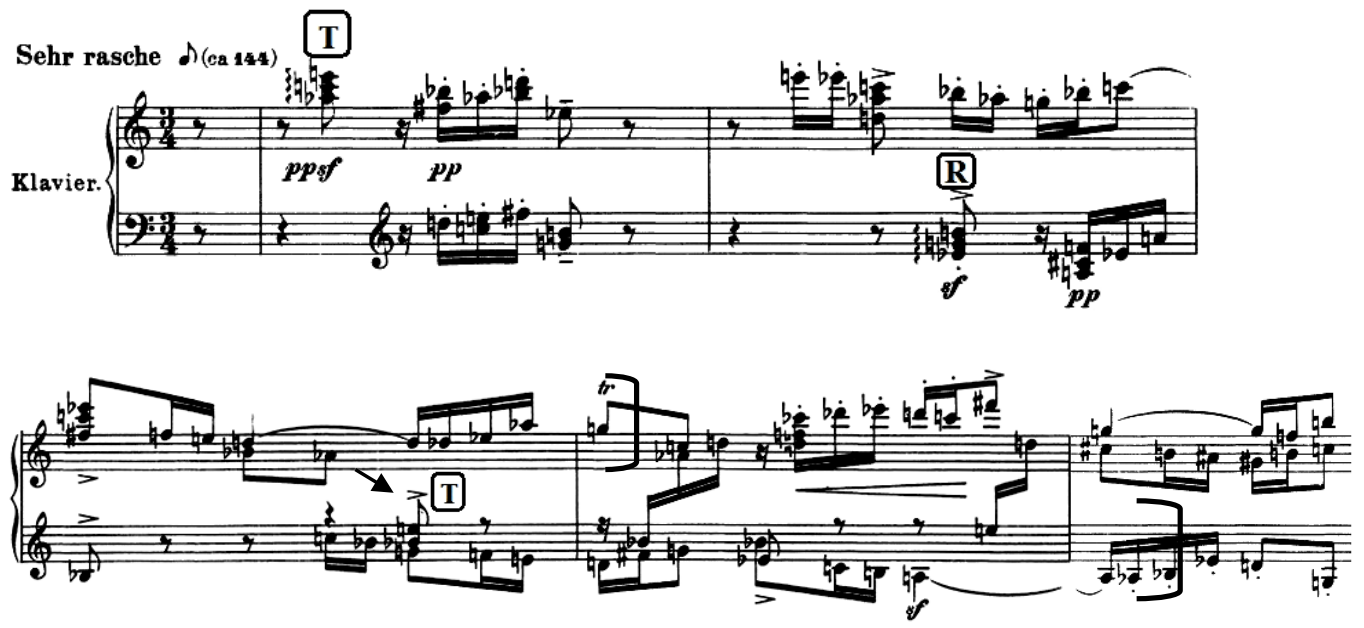

Fig. 13a Arnold Schönberg, Pierrot lunaire, Der Mondfleck, mm. 1-5

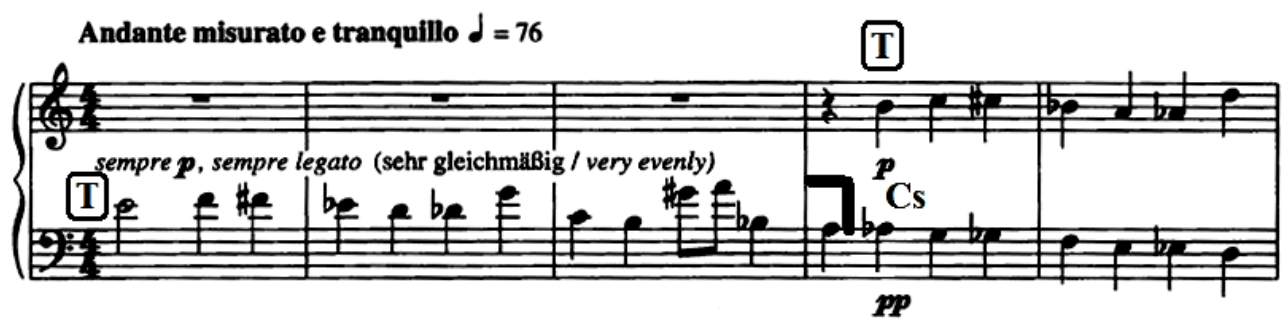




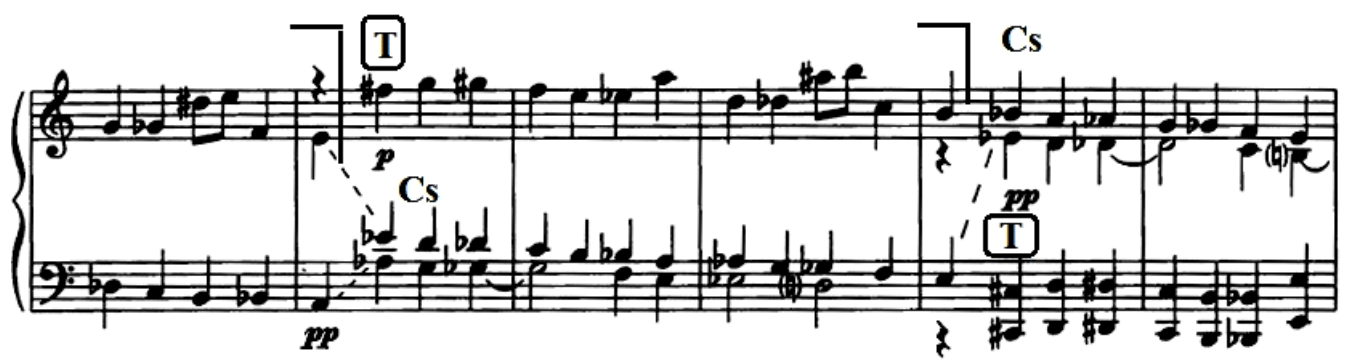

Fig. 13b György Ligeti, Musica ricercata, no. XI, mm. 1-11

The same category includes some of György Ligeti's works, who openly expresses his intention to take over, as a tribute, some of the old polyphonic techniques (Omaggio a Girolamo Frescobaldi).

- the response at a different interval than the fifth. In this category, a great number of opuses are aligned, complying with the sign of a complex modalism obtained by chromaticism, or as is the case of Hindemith or other composers, of a personal sonorous system. Moreover, in most cases, it is no longer a question of a proper response, but of a succession of entries according to criteria other than the traditional ones, which are based on the dominant tonal principle.

In Music for strings, percussion and celesta (1st movement) by Béla Bartók, the vocals entry is conducted according to a rigorous and originally structured tonal plan, which follows the circle of fifths both in ascending and descending directions, the latter two, at an extended fourth interval, thus resuming the first bipolar axis.

In Sonata for violin and piano, 3rd movement by Paul Hindemith, the expositive entries take place at a descending second interval, the last entry preceding the first episode ending the series of exposes in an octave interval, while replaying the theme in the original version (C-Bb-A-G-C). Between the extreme exposures on the same sound, we discover an intonational differentiation, made by enharmonic permutation, in order to avoid the vertical occurrence of a collision between two different alterations of the same sound (G\# with $\mathrm{Gb}-\mathrm{m}$. 19).

\section{Fugue}

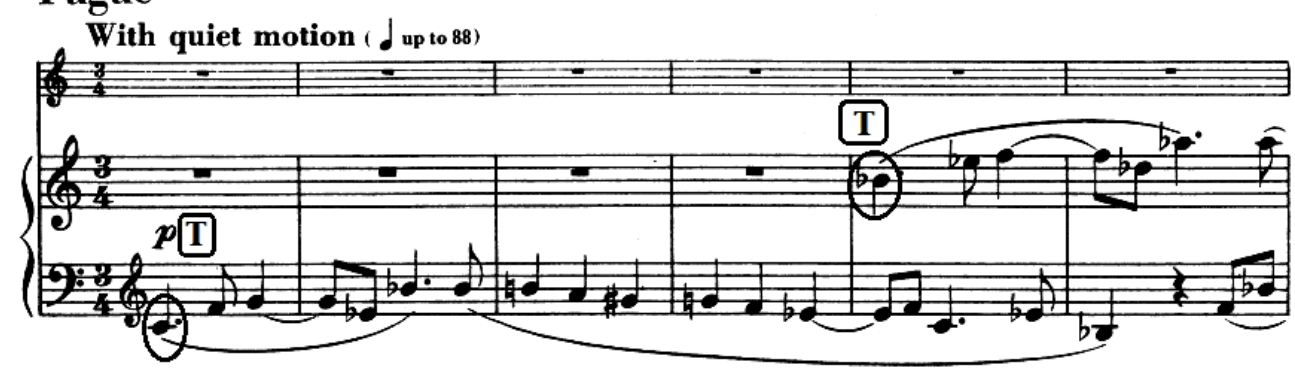



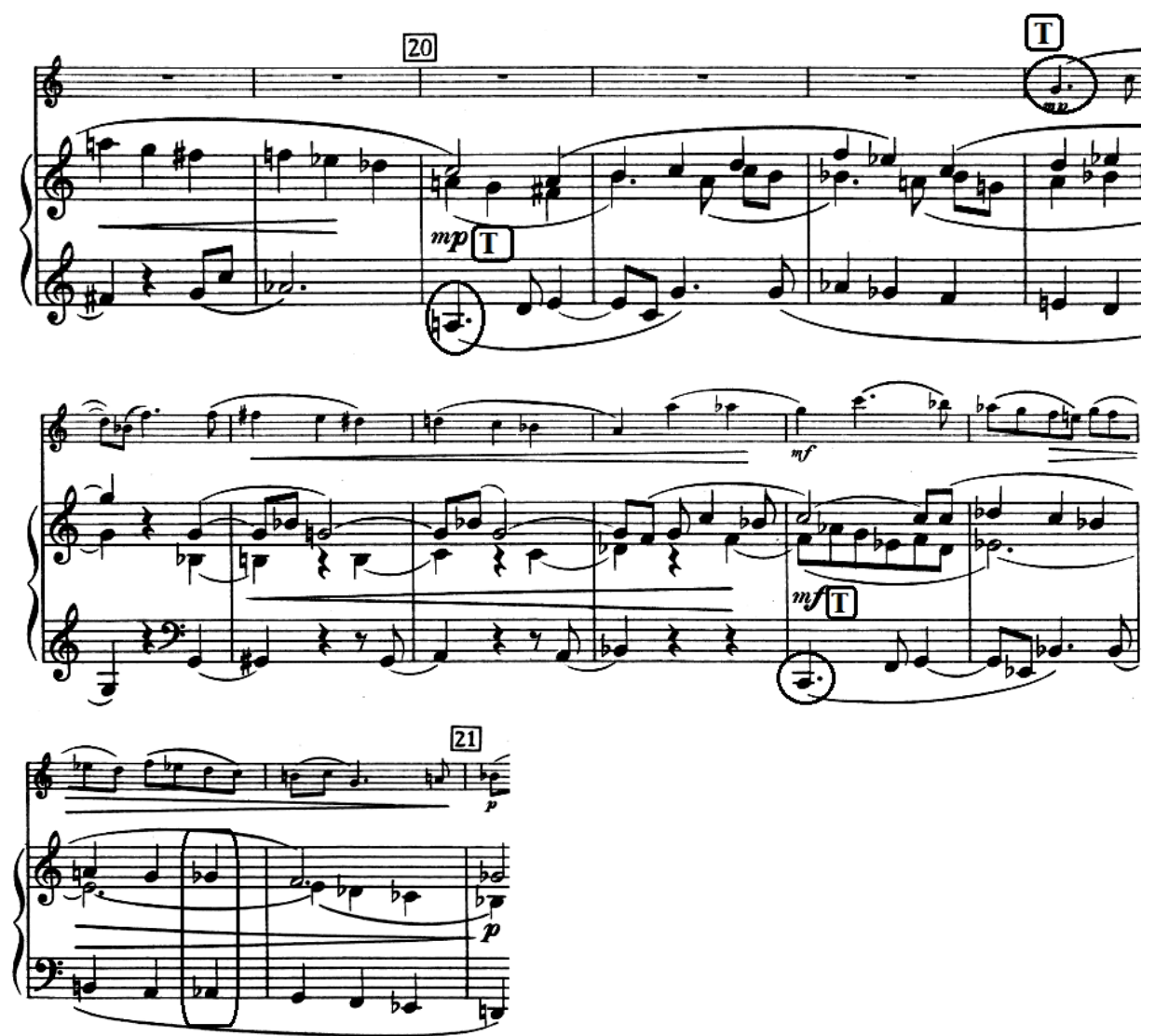

Fig. 14 Paul Hindemith, Violin sonata in C major no. 4, 3rd movement, mm. 1-21

In the same scalar layout, the entries in the exposition of the fugue in part IV of the Trio by the same composer are orderedin a wave-like manner $E-F \#$ $-A-A b$ (the B-A-C-H formula). We can see a preference of the composer for the imitation on the second and on the third, the latter being especially capitalized in Ludus tonalis ${ }^{2}$.

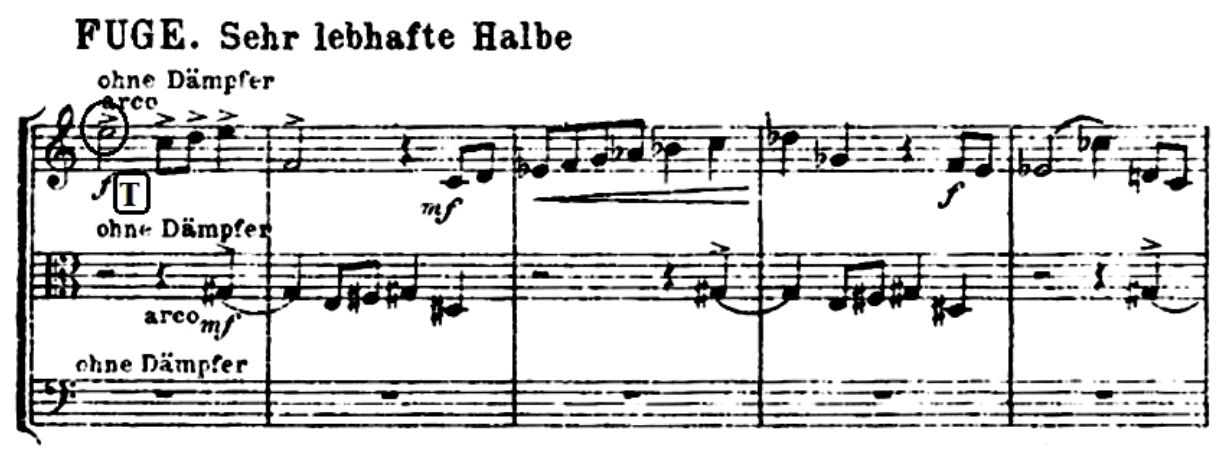

${ }^{2}$ An aspect noticed and commented by Dan Voiculescu in the work Polyphony of the 20th Century, Bucureşti: Editura Muzicală, 2005 
0
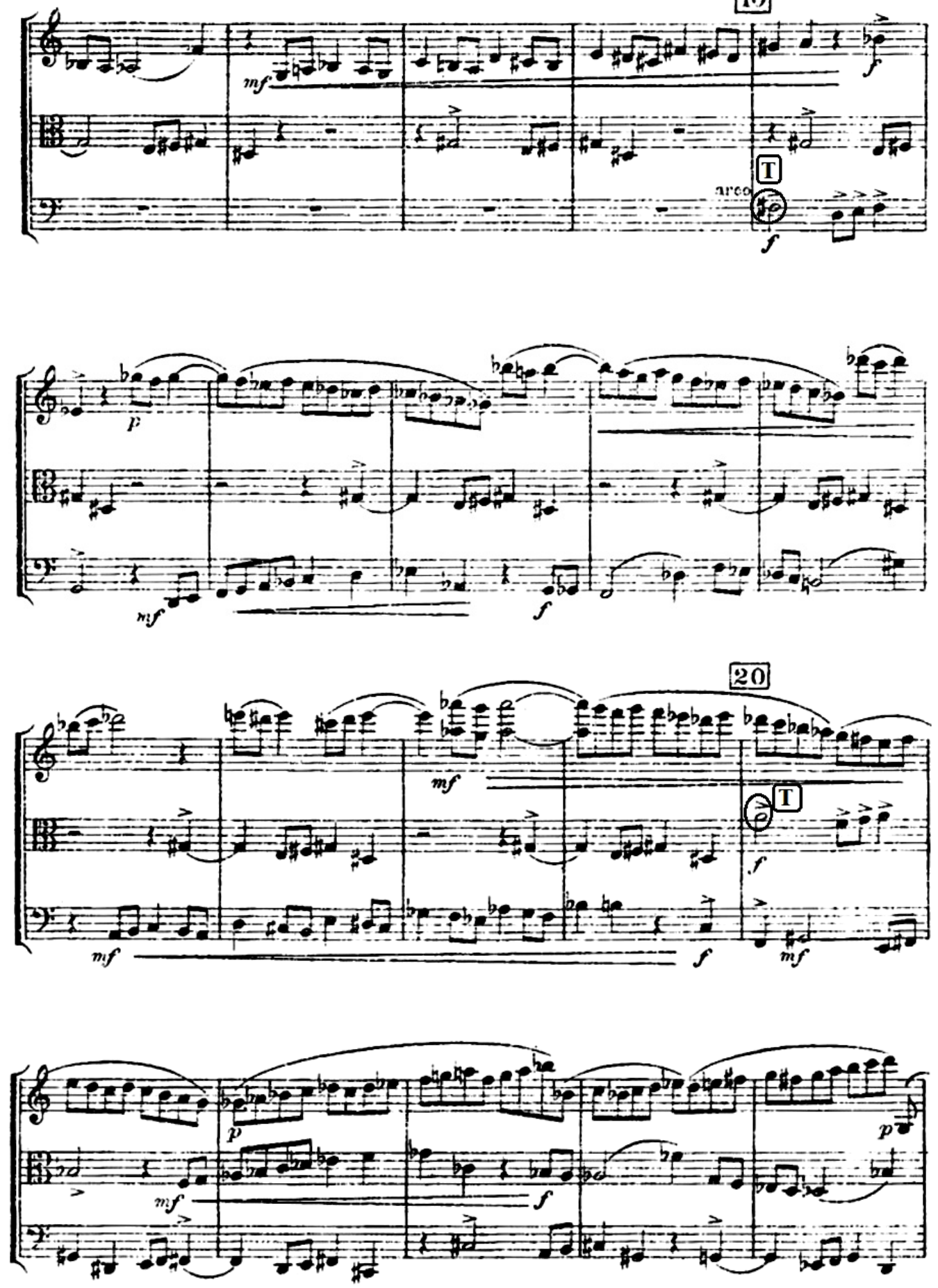

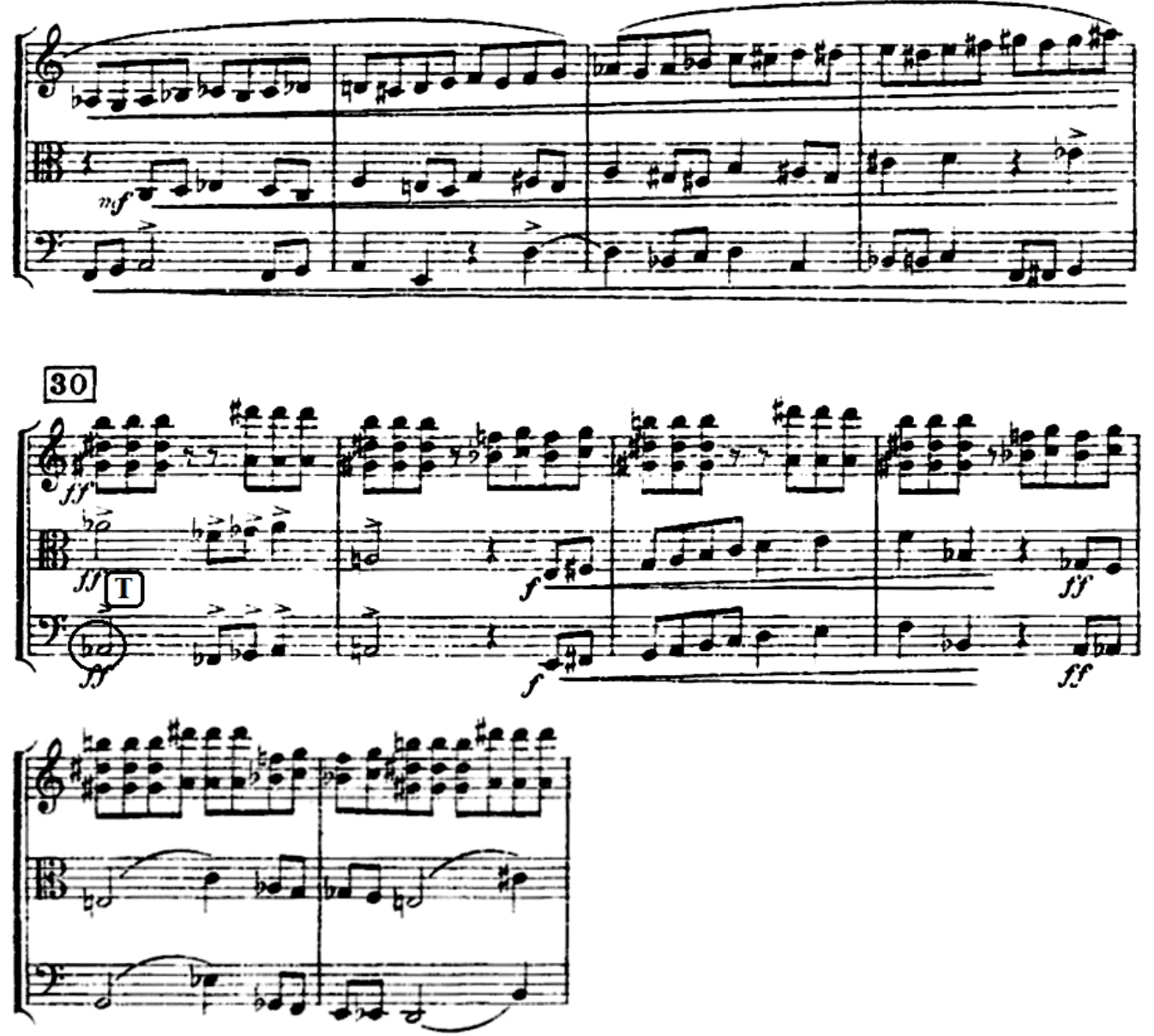

Fig. 15 Paul Hindemith, Trio op. 34, part IV, mm. 1-35

In Stravinsky's case (Octet, 3rd movement) we encounter what we might call self-imitation - the presentation of the theme and of the response at the same voice. The theme is exposed consecutively on the same tune by the 1st bassoon, the aspect of fugue exposition being suggested by the entry of an additional instrumental counter-subject, in the upper plan of the second appearance.

Other examples of changes in the relationship between thematic exposures in the exposition:

- At Tiberiu Olah (fugue from the Clarinet sonata) we encounter the succession of entries at a small ascending second interval - F-F\#-G. 
- The explicit deviation from the gravitational conception of classical tonalism is expressed by the three expositional entries of the theme from the Spielberg Symphony by Doru Popovici. The intonation cycle does not conclude in an octave interval, but in the distorted spirit of the diminished octave (8-), expressed by the relation $E$-Eb.

- An original succession, based on the perfect fifth / diminished fifth combination, can be found in the three voice exposition from the Sonata for solo violin by Marcel Mihalovici $-E b / A / B b$. The three sounds are not only found in the eight-element chromatic series (with 2 repetitive sounds) which forms the basis of the theme, but also represent its pillars: incipient, middle and final.

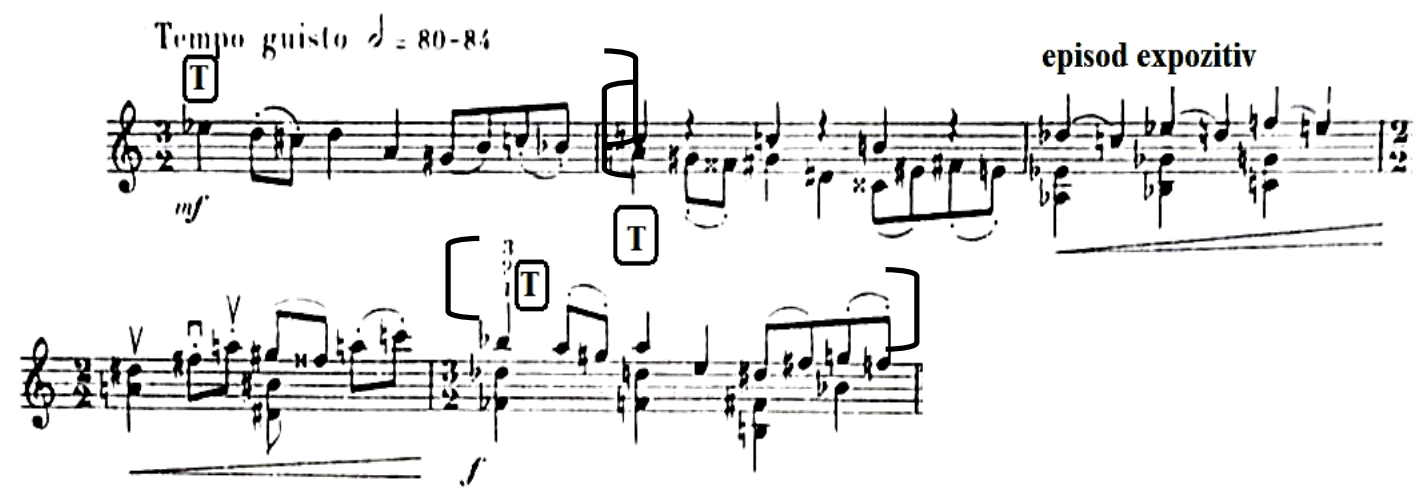

Fig. 16 Marcel Mihalovici, Sonata for solo violin, 2nd movement, Fugue, mm. 1-5

- In Ede Terényi's piece for organ, the thematic entries follow the order of pitches in the B A C H series - Bb-A - C - both in the exposition and in the stretto following it.

- How could we explain, based on a sonorous reasoning pertaining to functionality or non-functionality, the thematic exposures in Anamorphose by Şerban Nichifor or in Ernst Toch's Geographical Fugue? In such cases, from the entire rigorous imitative technique, only the principle of the successive entries of a "sonorous event" for all the voices involved in the polyphonic discourse is preserved.

An element of novelty in the 20th century fugue is the abandonment in some cases of the enunciation of the subject by a single voice, specific to the model of the Baroque period. In this situation, we also encounter various ways of accompanying the theme: 
* By introducing a free counterpoint, which can embrace more hypostases depending on the degree of repeatability and visibility during later statements of the subject;

* A free counterpoint that does not bear further treatment. For example, in Contrapuntal sketch by Gheorghe Firca;

* A counterpoint that becomes the ostinato pedal throughout the entire exposition. In Trio by Paul Hindemith (Fugue 1), the ostinato unfolds unchanged together with the first two entrances, being modified by successive transpositions to a different discursive plane (from $G \#$ to $F \#, C \#, G, A, D$ and finally to $A b$ ). The ostinato countersubject is based on the first motive of the theme;

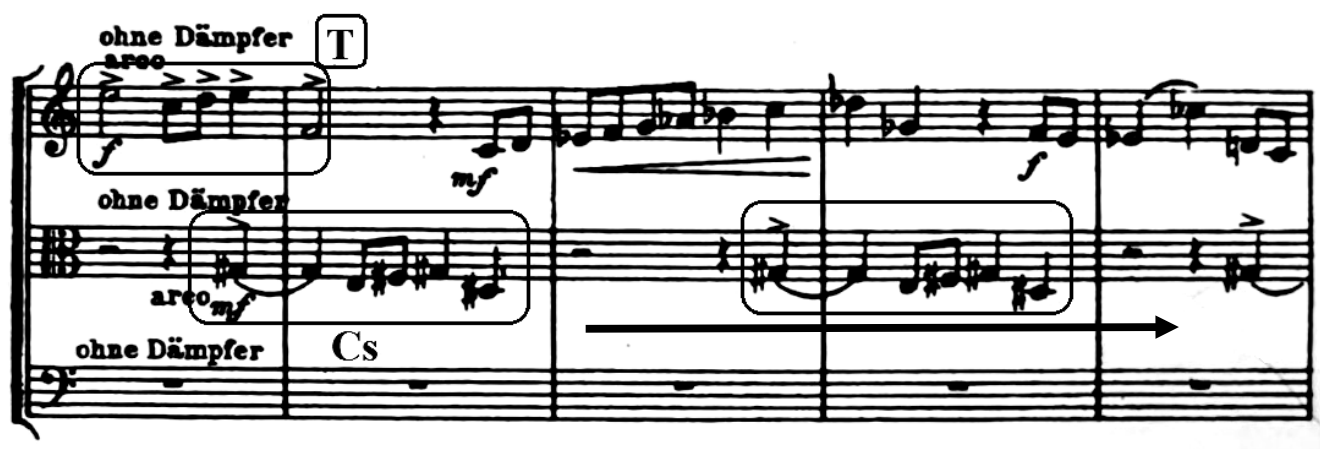

10

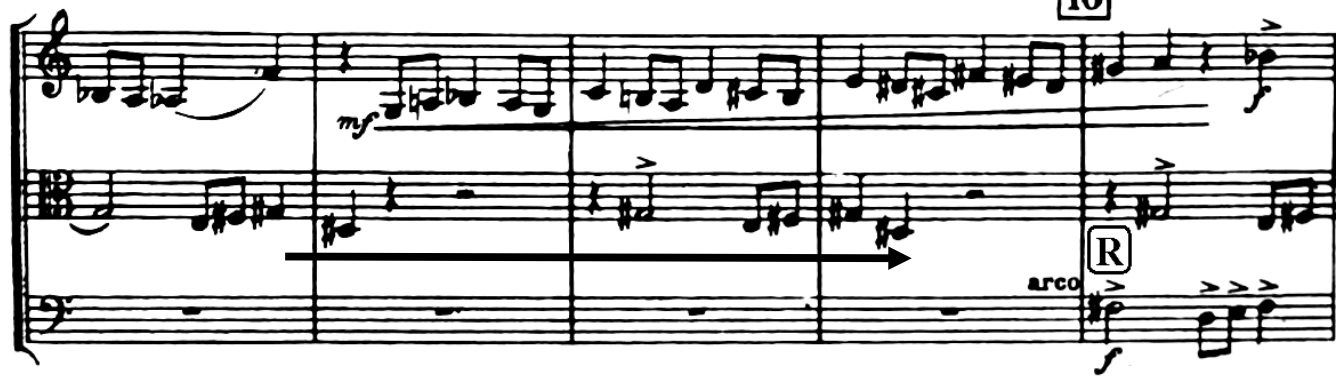

Fig. 17 Paul Hindemith, Trio, 4th movement, Fugue, mm. 1-10

* A particular type of exposition is the one found in the fugato from the String Quartet op. 7 by Bartók. The four statements placed at a descending fourth $(F-C)$ are grouped into pairs that feature two interesting peculiarities: the incipit in stretto and the partial similarity of the subject with the response (at a rhythmic level they are different), the latter taking the appearance of a counter-subject. 


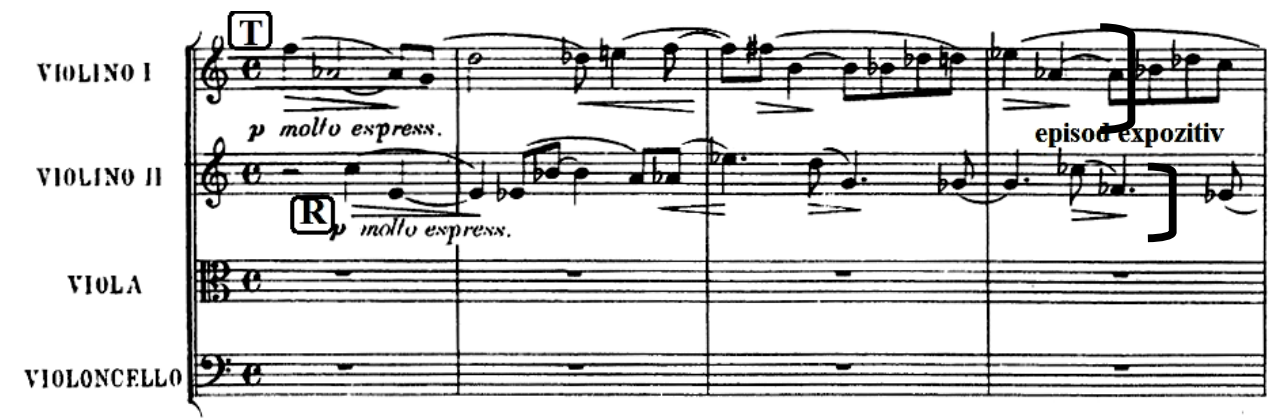

(1)
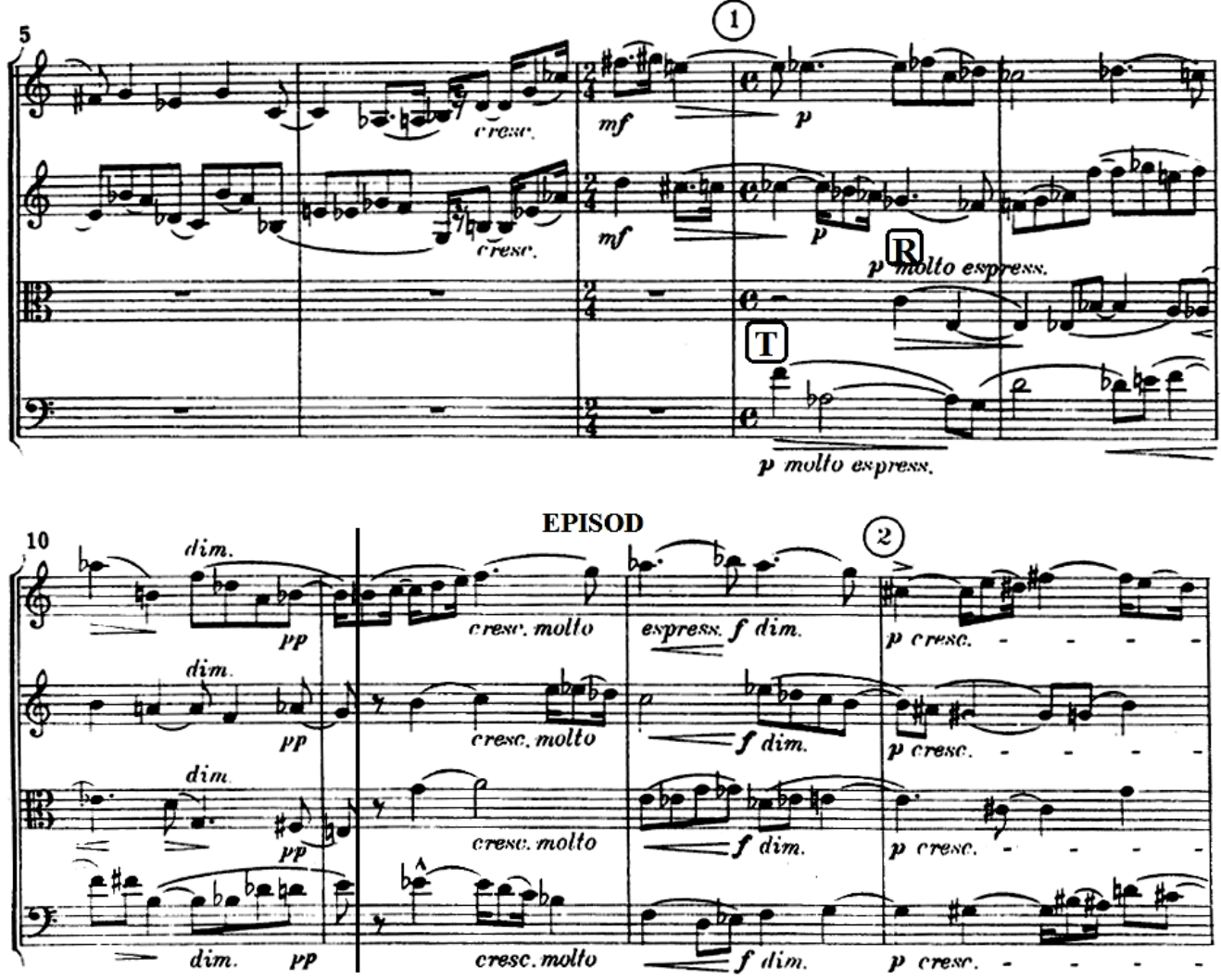

Fig. 18 Béla Bartók, String Quartet op. 7 no.1, 1st movement, mm. 1-13

* A particular case of great interest is the exposition of the second theme of the Organ composition fugue by Ede Terényi; 


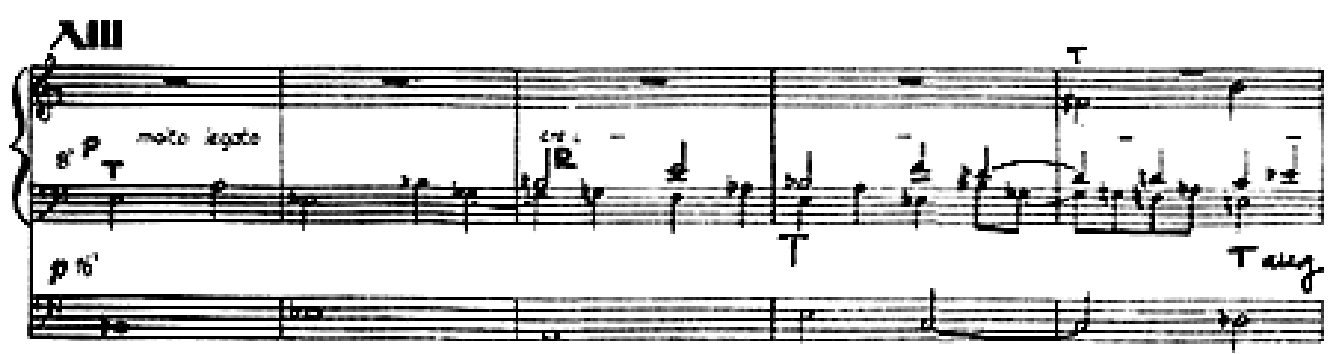

Fig. 19 Ede Terényi, Organ composition, mm. 25-29

After its initial statement, the theme is gradually imitated at all voices, its counterpoint being accomplished by repeating the same thematic lines in various rhythmic variants. Thus, the theme becomes a counterpoint to itself.

In the same context of counter-subjects, one can notice the preference of fugue composers of the 20th century for the strict counterpoint, sometimes with even two and up to three counter-subjects. The power of these accompanying lines of the theme determines their individualization, sometimes transforming them into stand-alone themes. In Quintet op. 57 by Dmitri Shostakovich, one of the two counter-subjects from the exposition will have a considerable constructive significance in the subsequent sections: it is resumed in the second episode as an actual theme, and in the final part, the first counter-subject is played in between the two statements of the subject, without being present in this section with the original function.

In the cycle 24 Preludes and fugues, Shostakovich also employs a wide variety of counter-subjects, the appearance of which during the fugue leading to the emergence of multiple counterpoint ratios.

\section{Conclusions}

As a musical idea with developmental virtues, referring to a certain structure of form, the theme ${ }^{3}$ far exceeds the significance of a simple musical idea precisely through its formal core function in the context of the respective architecture, becoming what Valentin Timaru (1990, pp. 196-198) designates as a formal landmark for musical forms with a refrain and for variational forms, and a form of reason for complex thematic forms.

The fluctuating and free use of means of sound expression in the twentieth century music determined the change of the concept of fleeing manifested through a new authenticity. The layout of the fugue form, directly

\footnotetext{
3 "We call the theme a musical idea of reference for the evolution of a musical discourse, in which the sound organization imparts some interdependence relations crystallized in a certain principle of superior organized musical form.” (Timaru, 2002, pp. 82-83)
} 
influenced by the innovations of the thematic concept, has embraced creative values that impose limits on the composer's fantasy and enrich it precisely through these constraints. The variety of means of conceiving the form of escape, manifested in the musical and structural parameters, becomes the starting point for the most unexpected hypostases of the form, often surprising in their modernity.

\section{References}

Scriabine, M. (1954). Athematisme et fonction thematique. Polyphonie, 9-10. Paris: Richard-Masse.

Timaru, V. (2002). Dicţionar noţional şi terminologic. Prolegomene ale unui curs de analiză muzicală [Dictionary of notion and terminology. Prolegomena of a music analysis course]. Oradea: Editura Universităţii din Oradea.

Timaru, V. (1990). Morfologia şi structura formei muzicale (Curs de forme şi analize muzicale) [Morphology and Structure of Musical Form (Course on Musical Forms and Analysis)], vol. I. Cluj Napoca: Academia de Muzică „Gh. Dima”.

Vancea, Z. (1973). Despre polifonie [About Polyphony]. Muzica, 6, 23-27. Bucureşti: UCMR.

Vancea, Z. (1980). Polifonia modernă [Modern Polyphony]. Muzica, 4, 37-42. Bucureşti: UCMR.

Voiculescu, D. (2000). Fuga în creaţia lui J. S. Bach [Fugue in the oeuvre of J.S. Bach]. Bucureşti: Editura Muzicală.

Voiculescu, D. (1974). Aspecte ale polifoniei în muzica românească contemporană [Features of polyphony in contemporary Romanian music]. Muzica, 6, 15-20. Bucureşti: UCMR.

Voiculescu, D. (2005). Polifonia secolului XX [Polyphony of the 20th Century]. Bucureşti: Editura Muzicală.

Voiculescu, D. (1979). Structuralismul şi polifonia [Structuralism and polyphony]. Lucrări de muzicologie [Musicology Papers], 8-9, 36-46. Cluj-Napoca: Academia de Muzică „Gh. Dima”. 